\title{
TERMINOLOGIA PĂSTORITULUI ÎN DIALECTUL AROMÂN ŞI ÎN DIALECTELE ITALIENE DIN PERSPECTIVA GEOGRAFIEI LINGVISTICE
}

\author{
NICOLAE SARAMANDU, MANUELA NEVACI
}

\section{INTRODUCERE}

Ocupațiile de bază ale aromânilor au fost, secole de-a rândul, păstoritul şi carvănăritul (transportul mărfurilor în caravane, pe cai). Ei au practicat şi practică, de asemenea, comerțul (negoțul) şi meşteşugurile (aromânii orăşeni). În mai mică măsură se ocupă de agricultură.

În lucrarea de față ne ocupăm de câteva aspecte etnografice din viața pastorală a aromânilor şi reflectarea lor în grai prin raportare la dialectele italiene din perspectiva geografiei lingvistice.

\subsection{Păstoritul la aromâni}

Modul de practicare a păstoritului presupunea transhumanța şi nomadismul, fiecare în parte cu caracteristicile sale.

Păstoritul transhumant presupune mutarea alternativă şi periodică a turmelor între două regiuni de climat deosebit, însoțite numai de păstori. (Th. Capidan 1942: 92): Th. Capidan, 1942, p. 93: „...păstorii din Tesalia, grupați în comunele Şescu, Alimeri, Bahce şi altele din apropierea oraşului Volo, Varna îşi trimiteau turmele de oi la munte numai sub conducerea câtorva păstori, iar restul familiilor rămâneau acasă, ocupându-se cu muncile câmpului".

Păstoritul în forma semi-nomadă implică aceeaşi mutare alternativă şi periodică concomitentă a turmelor, oamenilor şi întregului inventar gospodăresc, în aceleaşi aşezări.

Păstoritul în forma nomadă implică schimbarea periodică a locuințelor în locuri mai sigure şi în funcţie de calitatea păşunilor. Între tipul de viaţă seminomad şi transhumant, ultimul pare a fi fost cel mai vechi. La păstorii aromâni, transhumanța nu este atât de răspândită. Ea este practicată de nevoie în regiunile în care bărbații, putând-se ocupa şi cu altceva decât cu păstoritul, se duc o parte cu 
vitele la păscut, o altă parte rămân acasă, îndeletnicindu-se cu alte treburi. Nu se cunoaşte motivul care i-a determinat pe păstorii aromâni să nu continue această formă a păstoritului. Se pare că ei au evitat-o numai din pricina neplăcerilor ce se iveau în viața de familie. „La fărșeroți, spune Theodor Capidan, care de multe ori îşi schimbă locuințele după calitatea păşunilor, ultimul tip de viață semi- nomadă ia forma nomadă".

\subsection{Transhumanta în Italia}

Migrația turmelor de oi care coboară de pe munții înalți spre câmpie şi mare în nordul Italiei, la Trento, de exemplu, este reînnoită la începutul toamnei, în ciuda căutării rutelor alternative - cu unele inconveniente minore cauzate de traficul rutier şi de blocajele din trafic. Torma de oi e înoțită de păstori şi de câini, în special câinii din rasa „Lagorai”, care sunt foarte buni pentru a păstra efectivul compact şi a aduna în permanență toate animalele, precum şi pentru veghere. În turmă se află, de obicei, vreo cincisprezece măgari, mai mulți miei transportați într-o căruță specială.

\section{TERMENI PĂSTOREŞTI ÎN DIALECTUL AROMÂN ŞI ÎN DIALECTELE ITALIENE}

Termeni precum cheag, zer, coraslă, lapte, mulg, unt sunt prezenți atât în comunităţile de păstrori români cât şi în comunitățile de păstori italieni. Vom avea în vedere termenii cartografiați în lucrările:

Nicolae Saramandu, în colaborare cu Manuela Nevaci, Atlasul lingvistic al dialectului aromân, vol. II, Bucureşti, Editura Academiei Române (sub tipar) şi Karl Jaberg und Jakob Jud, Sprach- und Sachatlas Italiens und der Südschweiz [Linguistic and Ethnographic Atlas of Italy and Southern Switzerland], Zofingen, Ringier, 1928-1940.

\section{1. CHEAG < lat. coagŭlum}

Cheag în limba română < lat. coagŭlum, dintr-o formă cu metateză *cloagŭm, care stă la baza cuvântului în toate dialectele limbii române. În dialectul aromân, s-a păstrat o formă anterioară de evoluție fonetică, cl'ag, devenit în dacoromână cheag [ḱag] (cl' >ḱ). Termenul e atestat într-o arie largă în dialectul aromân, în graiurile aromâneşti vorbite din Bulgaria, R. Macedonia de Nord, Grecia, după cum se observa în rețeaua ALAR, h. 650, vol. II. În graiul fărșerot vorbit în Albania e concurat de rănd̆ă, cf. alb. rrëndës. 
În 3 puncte s-au notat:

15. Gopeş: sămiță di caş [lit. sămânță de caş]

37. Diviaca: iarbă di caş

33. Palioseli: măiauă < tc. maya.

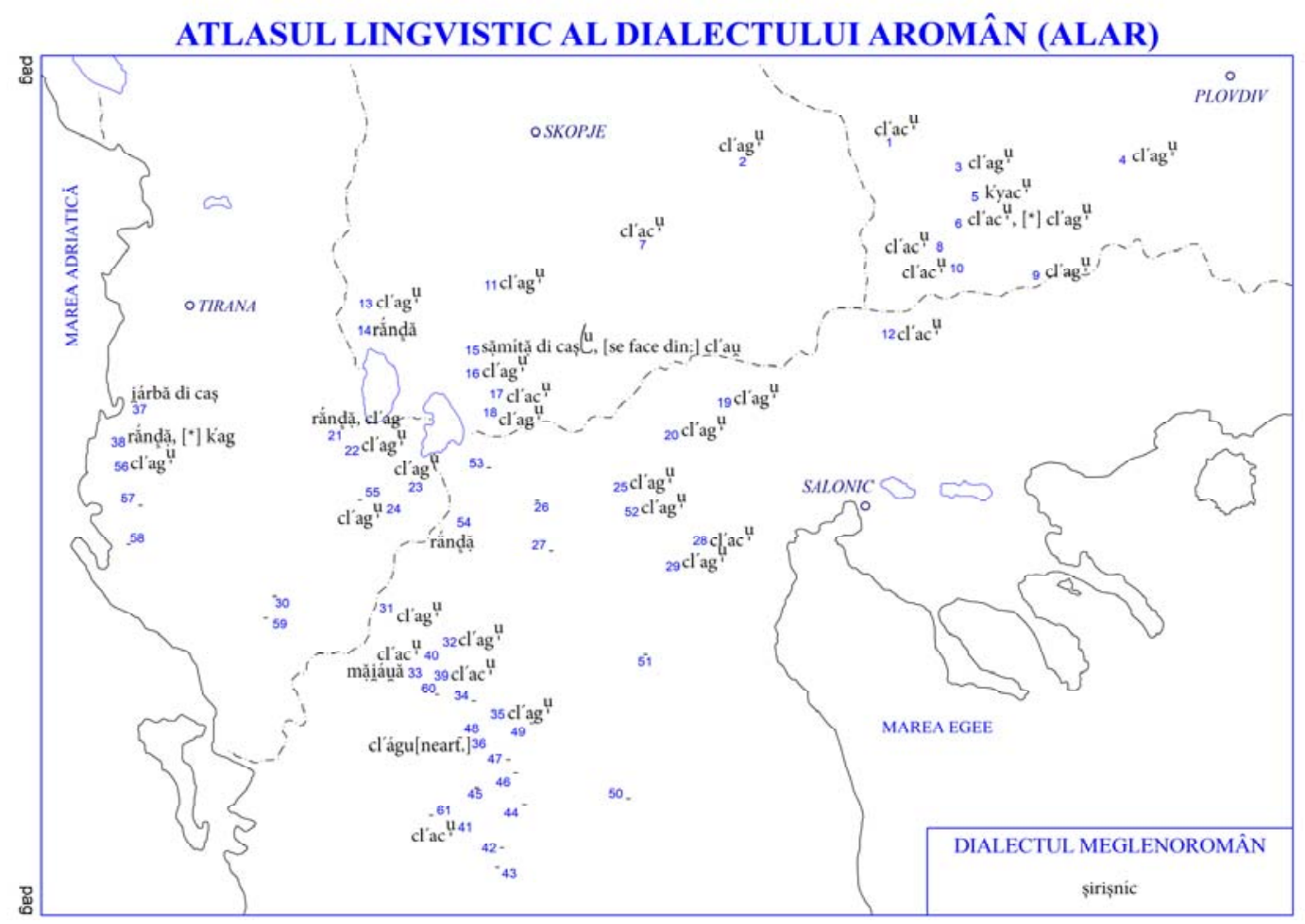

HARTA 650. CHEAG 'présure'; N. Saramandu, în colaborare cu M. Nevaci, ALAR, II [922].

Urmaşii lui coagŭlum în dialectele italiene sunt atestaţi într-o arie compactă în jumătatea sudică a Italiei, fiind difuz întâlniți în nord.

În latina clasică însemna atât „coş”, cât şi „lapte turnat”, în sens metonimic. Termenul se regăseşte în toate limbile romanice (it. caglia, gaglio, sp. cuajo, pg. coalho), dar cele două sensuri s-au păstrat doar în galo-romană (vezi FEW, 2, 818 ff., s.v. coagulum). În alte limbi romanice, de fapt, tipul de bază se referă exclusiv la conceptul de „coagulant”, cum se întâmplă, de exemplu, cu termenul italian caglio. 


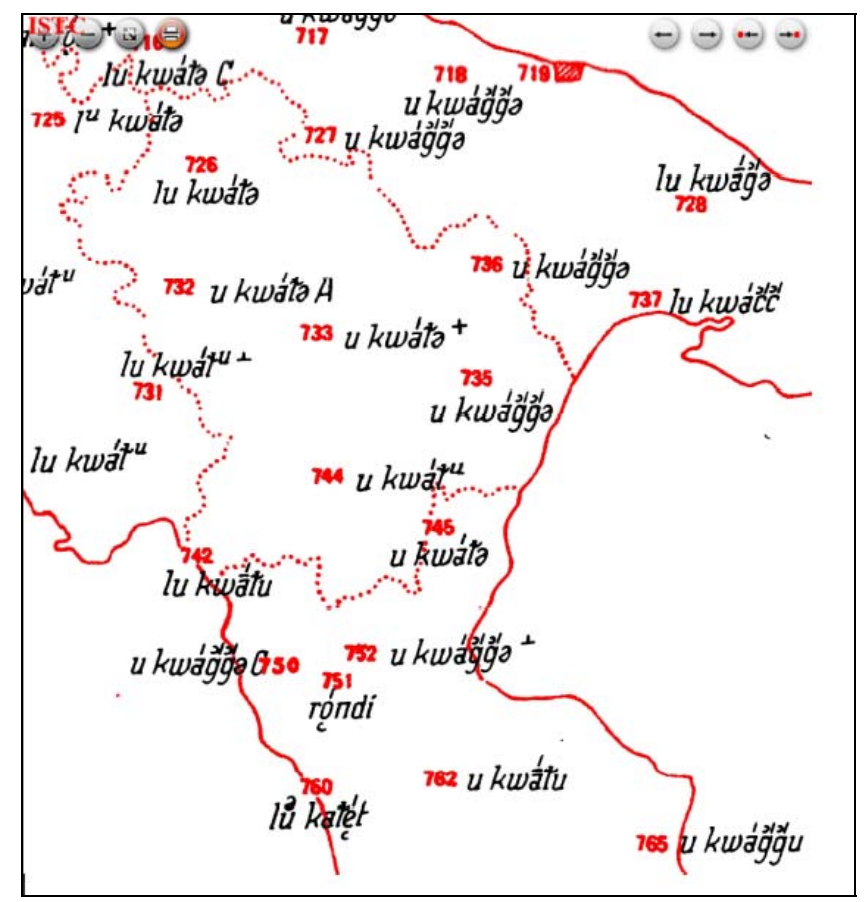

Karl Jaberg und Jakob Jud, Sprach- und Sachatlas Italiens und der Südschweiz, harta cheag.

II. 2. $\boldsymbol{Z E R}<$ lat. serum 'lichid galben-verzui care se separă din lapte, după coagulare, la prepararea brânzeturilor şi care este folosit pentru fabricarea lactozei, urdei'

În dialectul aromân, forma general cunoscută este dŏar. În Gopeş şi în Molovişte e atestată forma $z \breve{a r}$, cu $\boldsymbol{d}$ trecut la $z$, ca în dacoromână. Forma cu $z$ la inițială e întâlnită şi în dialectul meglenoromân: zor. După dicționarele româneşti, originea cuvântului e discutabilă. DA indică drept etimon, lat. serum (prin apropiere de zară).

Formele atestate izolat în italiană (tserio) şi în sardă (zoru), cu $s$ trecut la ț, ca în aromână $\boldsymbol{s}$ trecut la $\boldsymbol{d}$ sau cu $\boldsymbol{s}$ trecut la $\boldsymbol{z}$ ne ajută să acceptăm posibilitatea ca $z a ̆ r$ (zer) în limba română să provină din lat. serum, etimologie acceptată pentru formele din italiană. Termenul e atestat în cea mai mare parte a Italiei, cu excepția zonei de nord-vest, unde nu există un termen specializat, cuvântul atestat fiind o formă de la latte. În părțile centrală şi meridională ale Italiei forma care continuă pe lat. serum, păstrează la iniţială siflanta $s$, alături de care apar şi forme cu $s$ trecut la africata ț (tserio). Înregistrăm în Sardinia forme cu $s$ trecut la $z$ (zoru). 


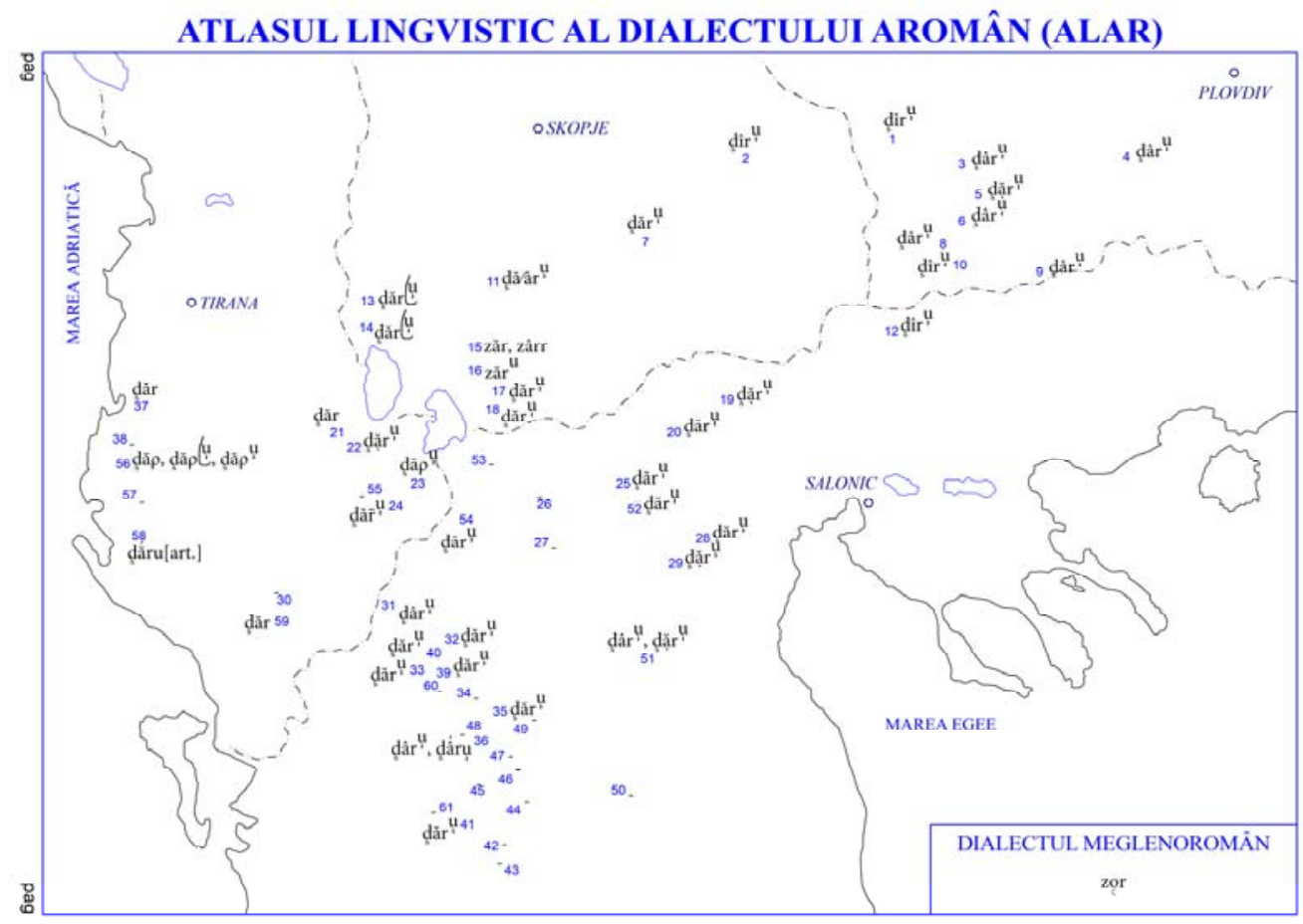

HARTA 654. ZER 'petit lait'; N. Saramandu, în colaborare cu M. Nevaci, ALAR, II [926].

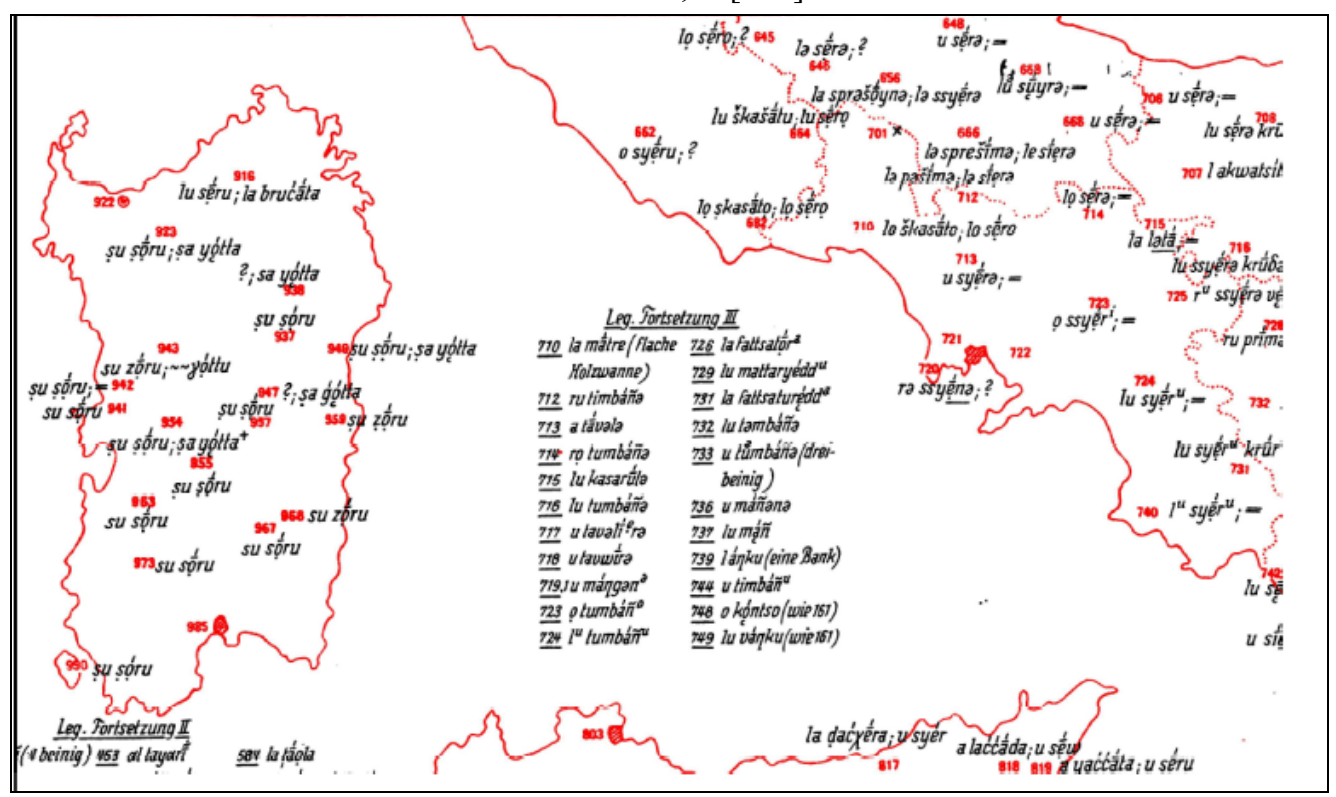

Karl Jaberg und Jakob Jud, Sprach- und Sachatlas Italiens und der Südschweiz, harta unt. 
II. 3. COLÁSTR $\breve{A}<$ Lat. cŏlostra - 1. 'Laptele unei mame imediat după naştere. 2. Lapte prins'.

În dacoromână e atestat în forma coraslă, fiind un cuvânt cu răspândire generală, aşa cum rezultă din atlasele dialectale. Rezultatul normal, corastrăa, a disimilat primul $r$ la $l$. În dialectul aromân, termenul e general.

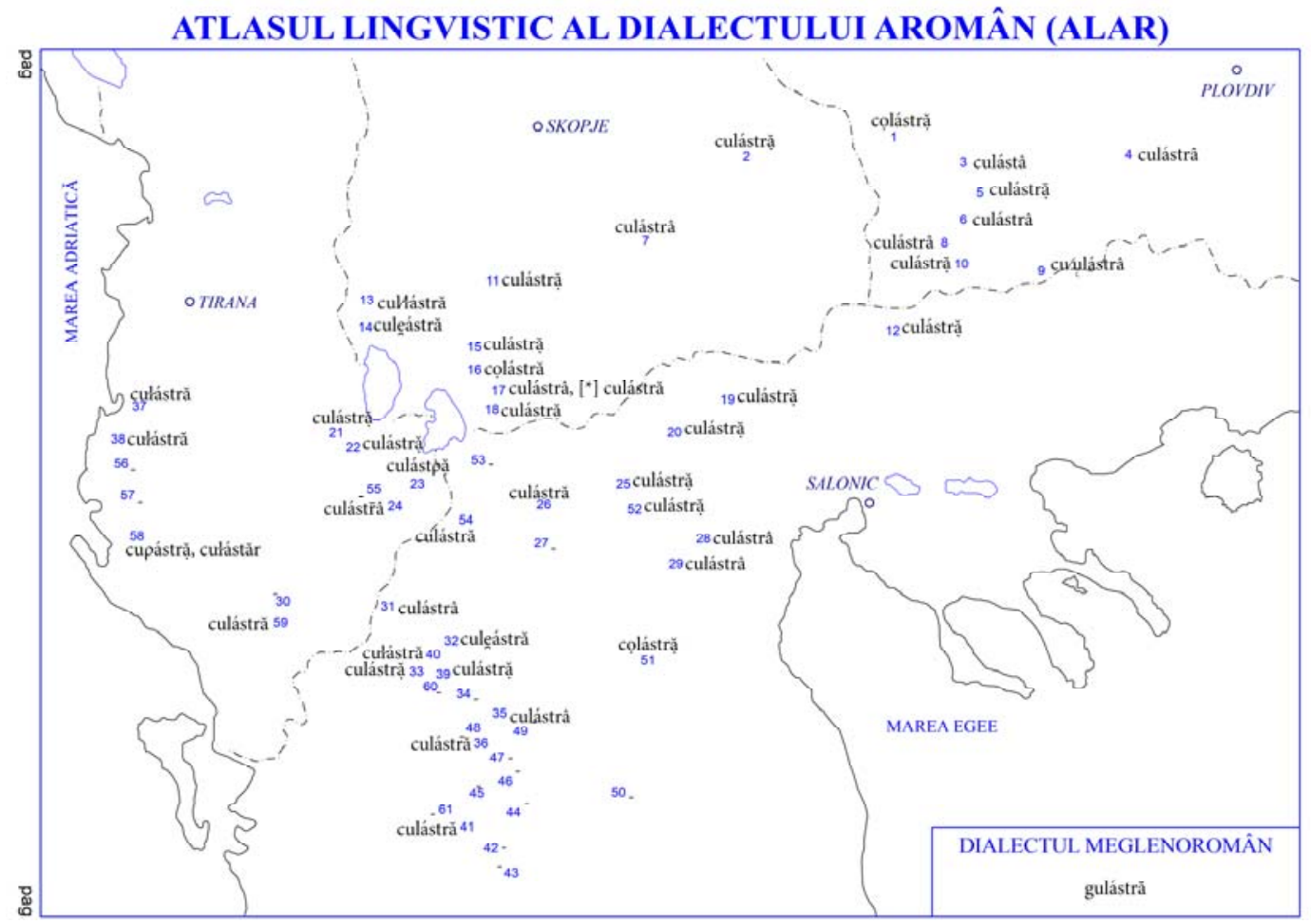

HARTA 575. CORASLĂ 'colostrum, premier lait après la délivrance’; N. Saramandu, în colaborare cu M. Nevaci.

Termenul descendent din latină este atestat într-o arie largă în sudul Italiei colostro (calostră, colostră) în rest fiind concurat de alți termeni. În Romania mai apare în castiliană: calostro (Corominas, I, 600), vechea aragoneză cullestru, asturiană culiestru.

Observăm că dialectele româneşti nord şi sud-dunărene participă la aria largă a Romaniei unde s-a păstrat termenul moştenit din latină, fiind transmis prin păstorii români în limbile balcanice, slave centrale şi meridionale şi chiar în

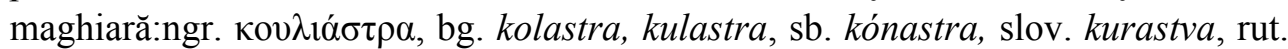
kołastra, kułastra, kułestra, magh. gulászt(r)a, gulesztra. 


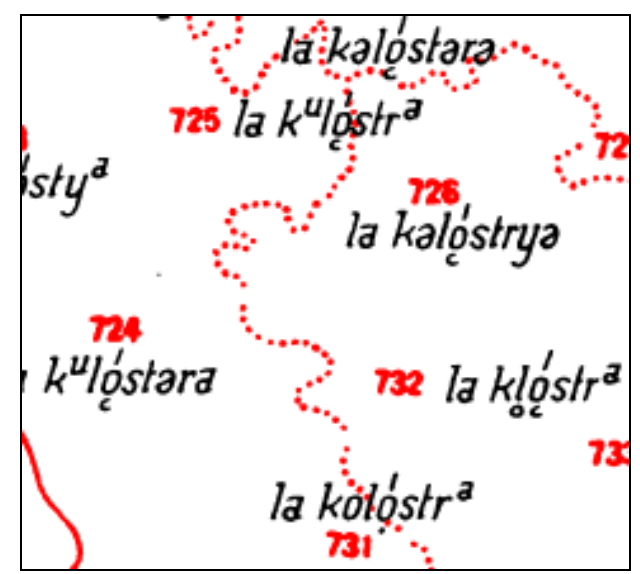

Karl Jaberg und Jakob Jud, Sprach- und Sachatlas Italiens und der Südschweiz, harta colastră.

\section{4. UNT $<$ lat. unctum}

În dialectele româneşti, s-au păstrat descendenții lat. ŭnctum. Dialectul aromân conservă forma arhaică umtu, cu grupul $m t<*^{*} m p t<n c t$ netrecut la $n t$, ca în dacoromâna actuală.

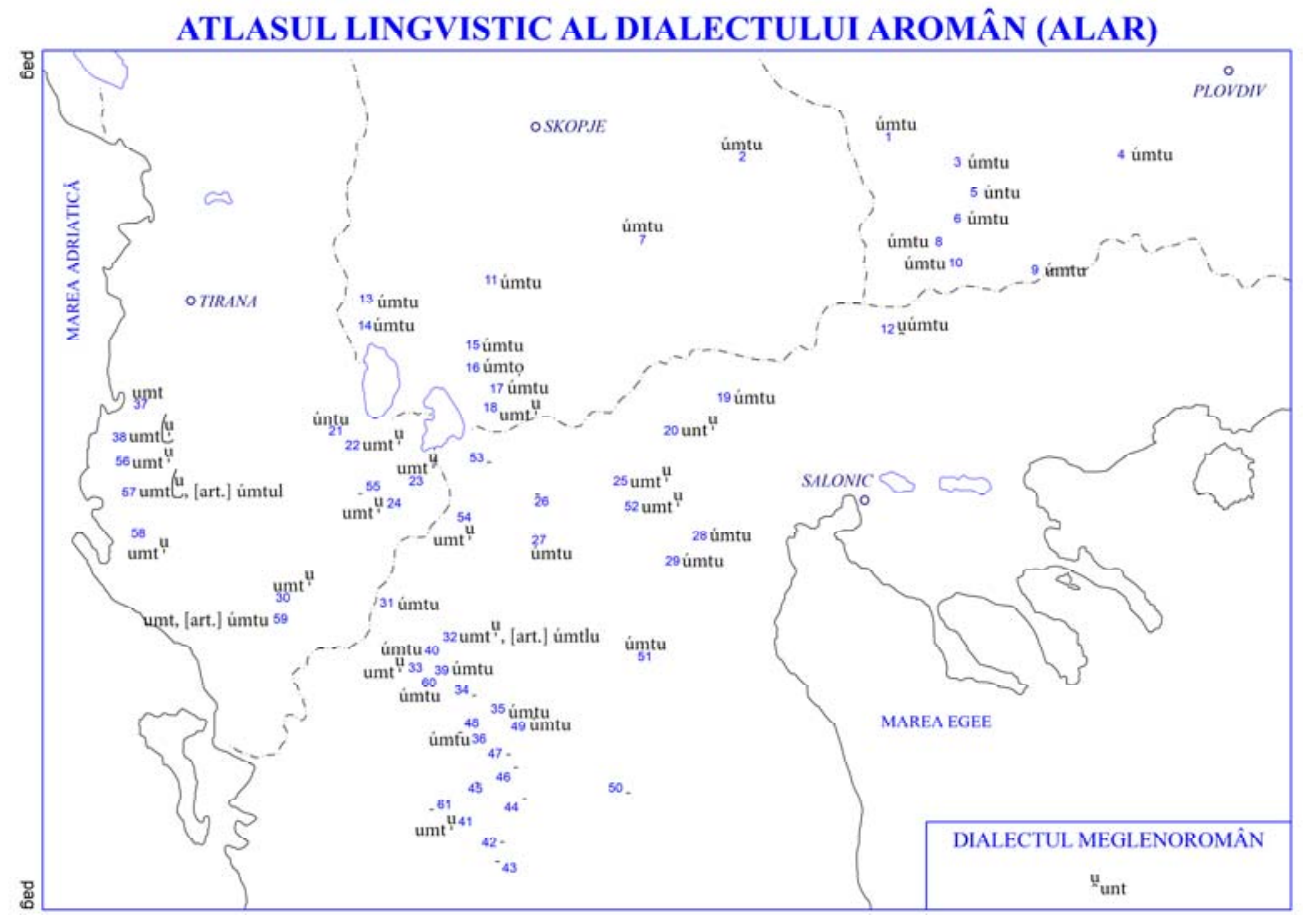

HARTA 579. UNT ‘beurre’; N. Saramandu, în colaborare cu M. Nevaci, ALAR, II [850]. 
În dilaectele italinenşti termenul provine din lat. ŭnctum „gras, unguent”, participiu trecut al verbului ŭngere ,a îngraşa, a lubrifia”. Prin substantivizarea verbului, el a dezvoltat sensul de ,grăsime" și, începând din secolul al II-lea d.Hr., 1-a dobândit şi pe acela de „unguent”. Ambele semnificaţii sunt prezente astăzi: sensul de „unguent” este menținut în cuvântul italian unguento şi în cuvântul piemontese oit. În italiană termenii proveniți din lat. ŭnctum sunt atestaţi izolat, în extremitatea nord-estică a Italiei, în ținutul Friul.

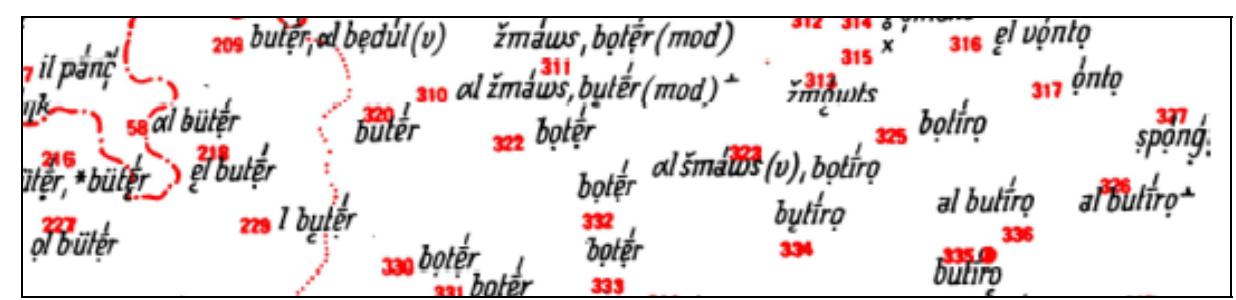

Karl Jaberg und Jakob Jud, Sprach- und Sachatlas Italiens und der Südschweiz, harta unt.

\section{II.5. MULG < lat. mŭlgēre}

Termenul e general în dialectele românești. Dialectul aromân moștenește forma de cojugarea a II-a din latină: muldém, muldét < lat. mŭlgēre, în timp ce în dialectul meglenoromân s-a făcut trecerea la conjugarea a III-a: múld̦im, múld̦iț.

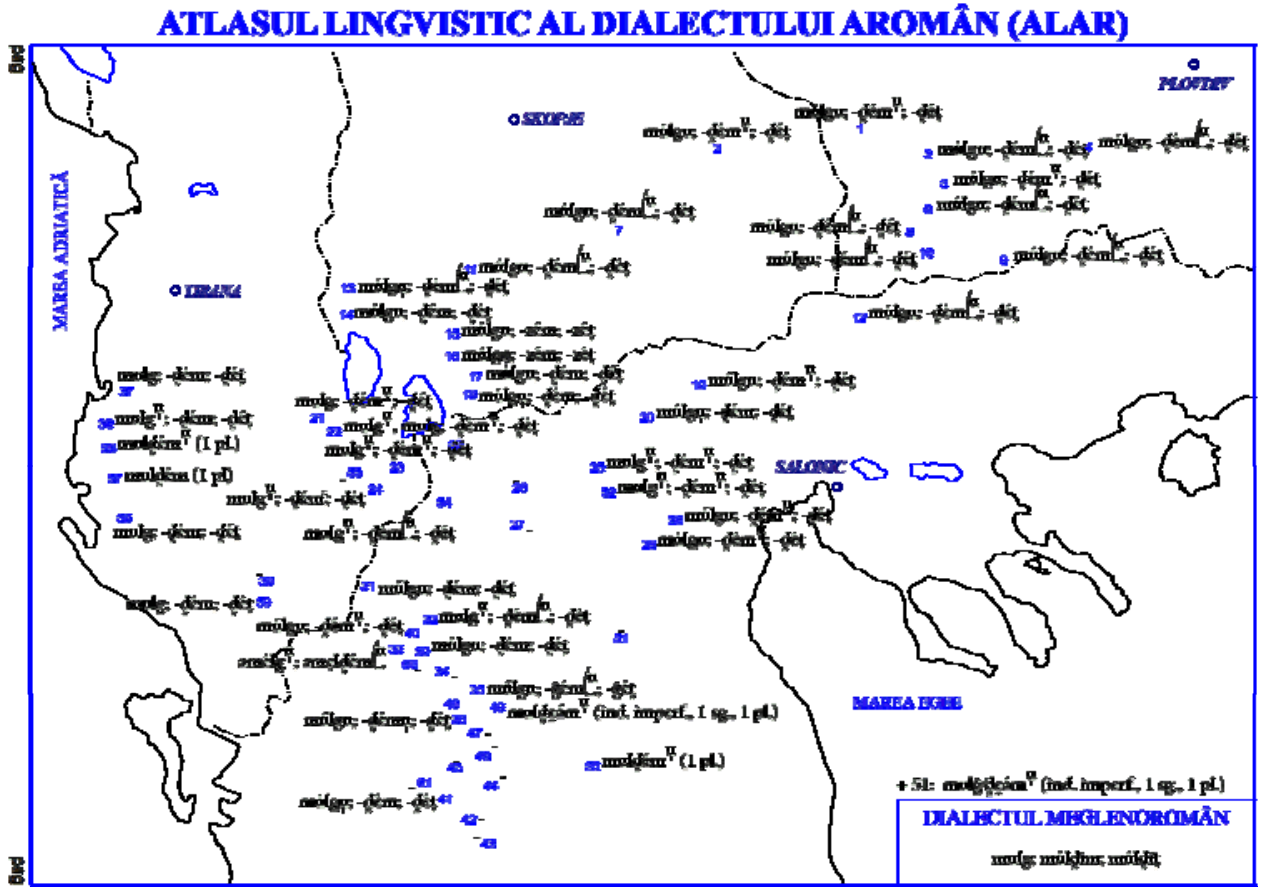

HARTA 642. MULG, ind. prez. 1 sg., 1-3 pl. 'je trais' [3 pl. = 1 sg.]; N. Saramandu, în colaborare cu M. Nevaci. 


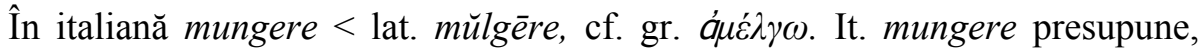
totuşi, o schimbare de conjugare față de mŭlgĕre şi o schimbare de la -l- la -n -. La origine se află i.e. *melǵ „lapte”. Termenul latinesc s-a păstrat în toate limbile romanice:it. mungere, v. fr. moudre, prov. molzer, cat. muñyir, astur. muñir, gal. moger, port. mungir.

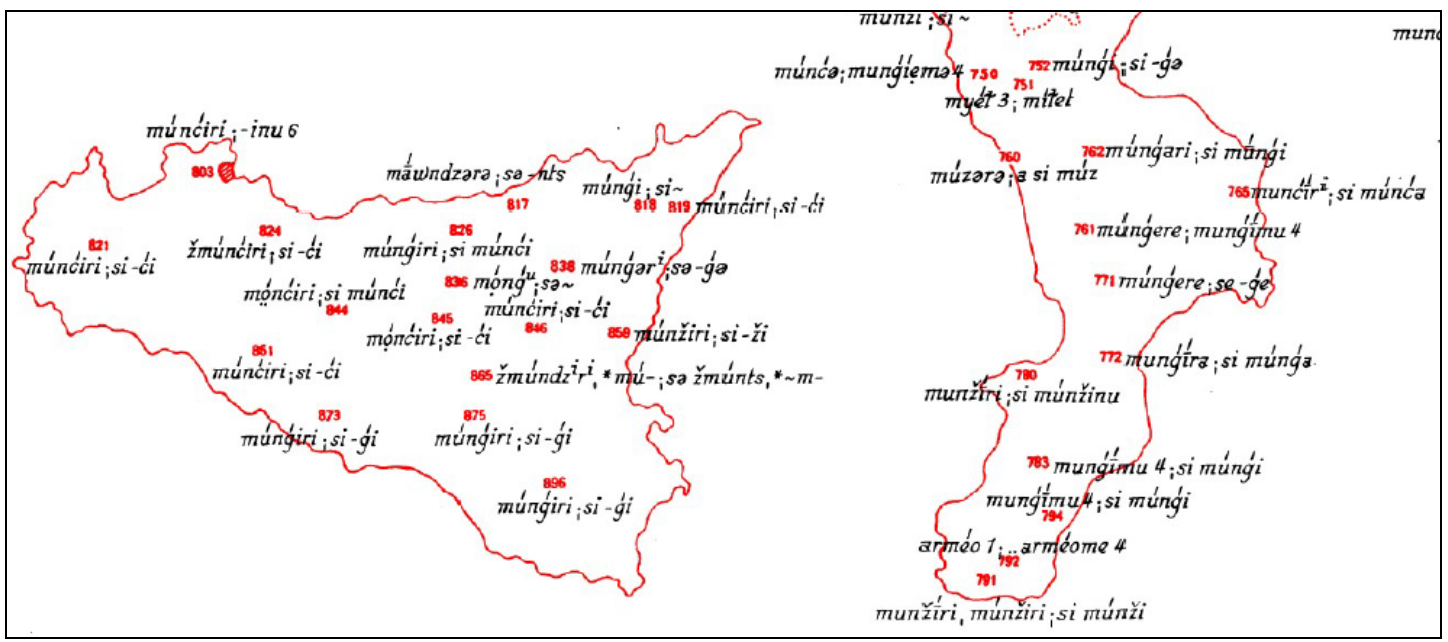

Karl Jaberg und Jakob Jud, Sprach- und Sachatlas Italiens und der Südschweiz, harta mulge.

III. Pentru ilustrarea păstrarea păstritului transhumant în formă pendulatorie, redăm, în continuare, un text înregistrat de Manuela Nevaci în 2016 în localitatea Samarina (Grecia) ${ }^{1}$ :

\section{[óili tú-arníu ]}

tóra aveám doi/ únu vḍi tóra câ víni ${ }^{\text {ră }}$ dóli ficoóri di híma / ațélù ficórlun-a meu de ase्रáră e्रará a meun //

[a tău]

ațélư lucreáăăă makínă/ lucreáḑă aftukínitu mári / astâmâțí tóra / ári ş-tóra dáu trei cupíi tẹ-a dárâ ațélù lúcru/ [ári]

doi súndu / doi sundu //

[in ári? tu ți horị aúáți Samarínă?]

\footnotetext{
${ }^{1}$ Manuela Nevaci (coord.), Carmen-Irina Floarea, Ionuț Geană, Teodora Toroipan, Convergențe lingvistice balcano-romanice în dialectele româneşti sud-dunărene, Editura Universității din Bucureşti, 2017.
} 


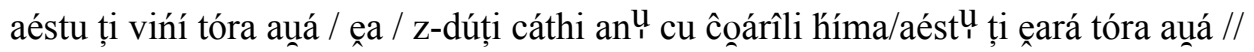
[cu cicicoárili z-dúți?]

cu ĉicooárâli z-dúți auáa ațéli exáste / [nu cu makína?]

éáste oh́ cu makína //

S2: nu poa z-dúcặ/ câțé va s-múlgă// tóra tọámna nụ áre muld̦eáre/ j-dúsi nihámự// aéstu aúá/ dúsi //

[cắti d̦ắli fáți?]

fáți un ’ meśu/

[unu mesù fáţi pi ĉicoóri]

[ş-pi-ịu ne्रaḑi pitù múnti?]

fúd̦i ísi híma Griviná / ş-ísi híma Calabắcă/ Discátă //

[pit ți hori trexáți?]

túti hoárili cắti suntu de्र-aúa pấnặ Lárisa //

[poț să-ń ḑăț cặtivá aşé niscắnti]

po zḑăcụ î/ ahurháşti de्रaoaena/ Poliméręa/ Filipéii/ Zmícse्रa/ ma híma Anávrita/

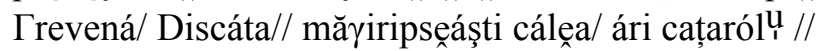

[aşé?] adárâ macaróni/ adárặ fâsúlự//

[ş-fúḑi cu mul'érili ma ş-fắră?]

fắrâ mul'ári // [fắrâ mul'érì]

nu u l'a mul'áréa/ [nu u l'a mul'áre्रa]//

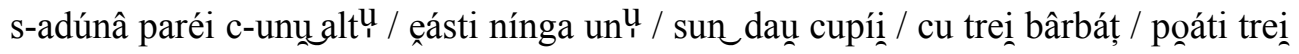
/ poáti pátru /

[poáti pátru/ aşéti] [ş-ma nínti fud̦eá tútă hoára ma maş bârbáț]

tútâ hoára vḑea/ me्रa tu [...] únă ńíli náu súti pân tu únă ńíli náu súti şaptiḑắţi /

[únă ńíl'i náu súti]

e tóra şaptiḑắț $[\ldots]$

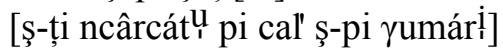

ngârca tútă páde्रa/ i ți aveámì di mul'érli / túti li ncărcắm nal ${ }^{\mathrm{t}}$ /

[grai pindean; Gachi, 61 de ani, Samarina, Grecia]

\section{[oile la iernat]}

acum aveam doi / unul plecă acum / că veniră amândoi băieții de jos [= din câmpie] / bîiatul acela de ieri seară era al meu //

[al tău] acela lucrează cu maşina // lucrează cu o maşină mare / acuma a încetat [să mai lucreze (nn.)] / are şi acum două / trei turme cu care face acel lucru [= practică acea ocupație] // [are] doi sunt / doi sunt//

[unde sunt? în ce sate? aici în Samarina?] ăsta care a venit acum aici merge în fiecare an pe jos / în vale / ăsta care este acum aici // [se duce pe jos?] pe jos se duce aici // acela este ... [nu cu maşina?] nu este cu maşina// 
S2: nu poate să se ducă căci trebuie să mulgă [oile (nn.)] acum toamna nu se mulg oile // a plecat puțin acesta de-aici / a plecat//

[câte zile face pe drum?]

S1: face o lună //

[merge o lună pe jos]

[şi pe unde merge prin munte?]pleacă direct jos / la Grevena şi drept în jos la Calabaca / la Discata//

[prin ce sate trece?] // ă! [prin ce sate trece?]// prin toate satele câte sunt de-aici până la Larisa// [poți să-mi spui câteva? / aşa câteva?] // pot să-ți zic eu / începe deaici / Polimeri / Filipei/ Smixi/ mai jos Anavrita / Grevena / Discata // îşi fac de mâncare pe drum / au casoletă /[aşa?] fac macaroane // [aşa] fac fasole //[şi pleacă cu femeile sau fără?]// fără femeie// [fără femeie]//pe femeie nu o ia//[pe femeie nu o ia]

se adună într-un grup unul cu altul / este încă unul // sunt două turme cu trei bărbaţi / poate trei / poate patru /

[poate patru / aşa// şi în trecut pleca tot satul? sau numai bărbații?]

pleca tot satul /uite ... în ...[б] $1900 / / 1970$ [1970] da, acum în anii 70 [şi ce încărcați pe cai şi pe măgari?]

încărcau toată zestrea / tot ce aveaam de la femei / pe toate le încărcau sus// [grai pindean; Gachi, 61 de ani, Samarina, Grecia]

\section{CONCLUZII}

Unitatea terminologiei păstoreşti în română şi italiană, continuatoare ale limbii latine, reprezintă o unitate care se extinde adesea la întreaga Românie. În dialectele limbii italiene unii termeni păstoreşti sunt concuraţi de sintagme motivate semantic, fenomen care se regăseşte uneori şi în dialectul aromân.

Este remarcabilă continuitatea între latină şi limbile romanice, fapt care arată că păstoritul este o ocupație de bază străveche la popoarele romanice. Prin păstorii români din nordul şi din sudul Dunării, termenii păstoreşti de origine latină s-au transmis în greacă, bulgară, slovenă, sârbă, polonă, cehă, maghiară, ucraineană. Aceasta arată că păstoritul a fost o ocupație de bază a românilor, practicată în forme evoluate, care s-au impus popoarelor cu care românii au venit în contact.

\section{BIBLIOGRAFIE}

Capidan 1942 - Th. Capidan, Macedoromânii. Etnografie, istorie, limbă, Bucureşti, 1942.

DER - Alexandru Ciorănescu, 1954-1966, Diccionario Etimológico Rumano, Biblioteca Filológica, Universidad de La Laguna, Tenerife. / A. Ciorănescu, 2002, Dicționarul etimologic al limbii române, Bucureşti, Saeculum I. O. 
FEW - Walther von Wartburg, Französisches etymologisches Wörterbuch. Eine Darstellung des galloromanischen Sprachschatzes, Berlin, Fritz Klopp, 1929.

ALR, II - Nicolae Saramandu, în colaborare cu Manuela Nevaci, Atlasul lingvistic al dialectului aromân, vol. II, Bucureşti, Editura Academiei Române (în curs de tipărire).

Karl Jaberg und Jakob Jud, Sprach- und Sachatlas Italiens und der Südschweiz [Linguistic and Ethnographic Atlas of Italy and Southern Switzerland], Zofingen, Ringier, 1928-1940.

Manuela Nevaci (coord.), Carmen-Irina Floarea, Ionuț Geană, Teodora Toroipan, Convergențe lingvistice balcano-romanice în dialectele românești sud-dunărene, Editura Universității din București, 2017.

REW - Wilhelm Meyer-Lübke, Romanisches etymologisches Wörterbuch, C. Winter, Heidelberg, 1911.

\title{
SHEPHERD'S TERMINOLOGY IN AROMAN DIALECT AND ITALIAN DIALECTS FROM THE LINGUISTIC GEOGRAPHY PERSPECTIVE
}

\begin{abstract}
The unity of the shepherd terminology in Romanian and Italian, continuators of the Latin language, shows a unit that often extends throughout Romania. In the dialects of the Italian language some pastoral terms are competed by semantically motivated phrases, a phenomenon that is sometimes found in the Aromanian dialect. The continuity between Latin and the Romance languages is remarkable, which shows that the shepherd is an ancient basic occupation of the Romance peoples. Through the Romanian shepherds from the north and south of the Danube, the Latin shepherd terms were transmitted in Greek, Bulgarian, Slovenian, Serbian, Polish, Czech, Hungarian, Ukrainian. This shows that shepherding was a basic occupation of Romanians practiced in evolved forms, which were imposed on the peoples with whom the Romanians came in contact.
\end{abstract}

Institutul de Lingvistică al Academiei Române „Iorgu Iordan - Alexandru Rosetti” București, Calea 13 Septembrie nr. 13 